\title{
KEMAMPUAN MAHASISWA MENGGUNAKAN KALIMAT EFEKTIF DALAM MENULIS KARYA ILMIAH
}

\author{
Heni Heryani \\ Program Studi PPKn, STKIP Pasundan \\ heniheryani65@gmail.com
}

\begin{abstract}
Abstrak
Penelitian ini bertujuan untuk mendeskripsikan karakteristik pola kalimat pada karya ilmiah mahasiswa Jurusan PIPS Prodi PPKn dan mendeskripsikan kesesuaian kaidah kalimat efektif bahasa Indonesia dalam karya ilmiah mahasiswa Jurusan PIPS Prodi PPKn dari segi diksi, struktur kalimat, dan logika. Penulis menggunakan metode deskriptif analitis yang berusaha menggambarkan data yang diteliti yang terjadi pada masa sekarang serta menguraikan aspekaspek yang menjadi fokus penelitian. Kualitas karya ilmiah setelah bahan ajar kalimat efektif diujicobakan adalah 1) penerapan aspek pilihan kata dan istilah dalam karya ilmiah baik, 2) penerapan aspek kesatuan, kesejajaran, kehematan, ketegasan/penekanan, dan kevariasian dalam karya ilmiah baik, 3) penerapan aspek kelogisan dalam karya ilmiah setelah bahan ajar digunakan baik, dan 4) penerapan kaidah ejaan dalam karya ilmiah bidang kewarganegaraan setelah bahan ajar digunakan cukup baik. Dari hasil penelitian disimpulkan bahwa penggunaan bahan ajar dalam perkuliahan berperan dalam meningkatkan kemampuan mahasiswa menggunakan kalimat efektif dalam menulis karya ilmiah bidang kewarganegaraan.
\end{abstract}

Kata Kunci: : kemampuan mahasiswa, kalimat efektif, karya ilmiah.

\begin{abstract}
This study aims to describe the characteristics of sentence patterns in college student's scientific work on the PIPS Department in Civic Education Study Program and describe the suitability of effective sentence rules in Bahasa indonesia of college student's scientific work at the PIPS Department in Civic Education Study Program in terms of diction, sentence structure, and logic. The author uses descriptive analytical methods that attempt to describe the researched data that occurs in the present and describes the aspects that are the focus of this research. The quality of scientific work after effective sentence teaching materials tested are 1) the application of aspects of choice of words and terms in good scientific work, 2) application of aspects of unity, alignment, efficiency, firmness / emphasis, and variance in good scientific work, 3) application of logic aspects in scientific work after the teaching materials are used well, and 4) the application of spelling rules in scientific work in the field of citizenship after the teaching materials are used quite well. From the results of the study it can be concluded that the use of teaching materials in lectures plays a role in improving the ability of college students to use effective sentences in writing scientific work in the field of citizenship.
\end{abstract}

Keywords: content, formatting, article.

\section{PENDAHULUAN}

Pelaksanaan perkuliahan di perguruan tinggi menuntut mahasiswa untuk lebih mandiri, terutama dalam melaksanakan tugas-tugas yang diberikan dosen. Salah satu tugas yang menuntut kemandirian adalah kegiatan menulis karya ilmiah. Dalam 
kurikulum di perguruan tinggi, pembinaan keterampilan menulis karya ilmiah tentulah sangat berharga sebab dapat melatih mahasiswa untuk berpikir secara ilmiah melalui tugas-tugas perkuliahan yang diberikan dosen. Sebagai insan akademis, mahasiswa tidak terlepas dari kegiatan menulis karya ilmiah. Karya-karya tersebut berupa makalah, laporan buku, dan skripsi sebagai tugas akhir untuk memperoleh gelar kesarjanaan.

Kegiatan menulis karya ilmiah oleh mahasiswa sering dianggap sebagai tugas yang berat. Anggapan tersebut timbul karena kegiatan menulis memerlukan banyak tenaga, waktu, serta perhatian yang sungguh-sungguh. Di samping itu, kegiatan menulis karya ilmiah menuntut keterampilan yang kadang-kadang tidak dimiliki oleh mahasiswa. Hal ini terbukti dengan munculnya keluhan-keluhan lemahnya kemampuan menulis karya ilmiah di kalangan mahasiswa. Keluhan tersebut muncul dari para guru, dosen, atau pemerhati bahasa Indonesia. Skripsi, makalah, dan laporan buku ditulis dengan rangkaian kalimat yang tidak efektif. Persoalan di atas tidak terlepas dari komponen penentu keberhasilan pembelajaran, yaitu guru (dosen), siswa (mahasiswa), materi pengajaran, sistem pendidikan, proses belajar mengajar, dan komponen lainnya.

Salah satu komponen yang dapat menunjang ketetampilan menulis karya ilmiah adalah materi perkuliahan kalimat efektif yang terdapat dalam mata kuliah Bahasa Indonesia. Materi perkuliahan kalimat efektif diarahkan agar mahasiswa mampu menerapkannya dalam tugas-tugas perkuliahan, seperti membuat makalah, membuat laporan, dan menulis skripsi. Dalam karya ilmiah bidang kewarganegaraan, penulis menemukan berbagai kesalahan penggunaan kalimat. Kesalahan-kesalahan penggunaan kalimat tersebut menyebabkan kalimat tidak efektif. Dengan demikian, karya ilmiah yang ditulis oleh mahasiswa Jurusan PIPS Prodi PPKn sampai saat ini masih memperlihatkan kesalahan dilihat dari segi keefektifannya. Banyak kalimat dalam karya ilmiah tidak memiliki ketepatan pemilihan kata, tidak memenuhi persyaratan struktur yang benar, dan tidak memenuhi kelogisan dalam berpikir. Kalimat dikatakan efektif apabila memenuhi persyaratan 1) pemilihan katanya tepat, jelas, lazim, 2) strukturnya memperlihatkan 
kesatuan, kesejajaran, kehematan, ketegasan, dan kevariasian, 3) kalimat sesuai dengan nalar/ logika berpikir, dan 4) penerapan kaidah ejaannya benar.

Berdasarkan permasalahan di atas, penelitian ini bertujuan mendeskripsikan karakteristik pola kalimat pada karya ilmiah mahasiswa Jurusan PIPS Prodi PPKn dan menganalisis kesesuaian kaidah kalimat efektif bahasa Indonesia dalam karya ilmiah mahasiswa Jurusan PIPS Prodi PPKn dari segi diksi, struktur kalimat, dan logika.

Konsep kalimat efektif dikenal dalam hubungan fungsi kalimat sebagai alat komunikasi. Dalam hubungan ini, setiap kalimat terlibat dalam proses penyampaian dan penerimaan. Apa yang disampaikan itu mungkin berupa ide, gagasan, pesan, pengertian, atau informasi. Kalimat dikatakan efektif bila mampu membuat proses penyampaian dan penerimaan itu berlangsung dengan sempurna. Kalimat efektif mampu membuat penerima atau penanggap mereaksi sebagaimana yang diharapkan penyampai.

Kalimat efektif adalah kalimat yang dapat mengungkapkan gagasan, pikiran, dan perasaan dengan tepat ditinjau dari segi diksi, struktur, dan logikanya. Dengan kata lain, kalimat efektif selalu berterima secara tata bahasa dan makna. Sebuah kalimat dikatakan efektif apabila mencapai sasarannya dengan baik sebagai alat komunikasi. Kalimat dikatakan efektif apabila memenuhi persyaratan 1) pemilihan katanya tepat, jelas, lazim, 2) strukturnya memperlihatkan kesatuan, kesejajaran, kehematan, ketegasan, dan kevariasian, 3) kalimat sesuai dengan nalar/ logika berpikir, dan 4) penerapan kaidah ejaannya benar (Putrayasa, 2007).

\section{METODE}

Penulis menggunakan metode deskriptif analitis yang berusaha menggambarkan data yang diteliti yang terjadi pada masa sekarang serta menguraikan aspek-aspek yang menjadi fokus penelitian. Pernyataan tersebut sejalan dengan pernyataan Surakhmad (1982: 139) bahwa metode penelitian deskriptif tertuju pada pemecahan masalah yang ada pada masa sekarang. Ciri-ciri metode deskriptif adalah (1) memusatkan diri pada masalah-masalah aktual dan (2) data yang dikumpulkan mula-mula disusun, dijelaskan, kemudian dianalisis. Data yang diperoleh dalam penelitian ini dideskripsikan kemudian dilakukan penafsiran 
dan penganalisisan terhadap deskripsi data penelitian untuk memperoleh deskripsi yang mendalam.

Data penelitian ini berupa data tertulis yang terdapat dalam makalah mahasiswa semester kedua Jurusan PIPS Prodi PPKn, data pelaksanaan perkuliahan di kelas, data karya ilmiah yang dibuat pada awal perkuliahan dengan bahan ajar yang selama ini digunakan, dan data karya ilmiah yang dibuat oleh mahasiswa setelah bahan ajar yang baru tersusun dan diujicobakan. Sesuai dengan tujuan penelitian ini, pengambilan sampel dilakukan secara purposive, yakni pengambilan sampel atas tujuan tertentu.

Untuk mendapatkan data yang relevan dengan rumusan masalah dan tujuan penelitian, pengambilan data dilakukan dengan menganalisis dokumen digunakan untuk mendapatkan data-data penggunaan kalimat dalam makalah mahasiswa Jurusan PIPS Prodi PPKn semester genap. Tulisan mahasiswa dianalisis dan dinilai dengan menggunakan pedoman penilaian. Selain itu, pengambilan data dilakukan dengan mengkaji bahan ajar/materi perkuliahan kalimat efektif yang selama ini digunakan.

Instrumen penelitian ini terdiri atas lembar panduan analisis dokumen, lembar observasi, pedoman wawancara, angket, dan pedoman analisis karya ilmiah. Lembar panduan analisis dokumen digunakan untuk menelaah materi kalimat efektif yang selama ini digunakan. Lembar observasi digunakan untuk mengamati perkuliahan di kelas. Hal-hal yang diamati adalah aktivitas dosen dan mahasiswa. Setelah data penelitian diperoleh, langkah selanjutnya adalah menganalisis data tersebut sesuai dengan rumusan masalah dan tujuan penelitian.

Teknik analisis data dilakukan dengan mendeskripsikan karakteristik karya ilmiah mahasiswa Jurusan PIPS Program Studi PPKn, mendeskripsikan dan menganalisis bahan ajar kalimat efektif yang selama ini digunakan, dan menganalisis penggunaan kalimat dalam makalah bidang kewarganegaraan berdasarkan pilihan kata, penerapan struktur kalimat efektif, penerapan aspek logika, dan penerapan kaidah ejaan. 


\section{HASIL DAN PEMBAHASAN}

Karya ilmiah mahasiswa Jurusan PIPS Prodi PPKn diperoleh dari tugas makalah bidang kewarganegaraan. Karya ilmiah yang dianalisis berupa makalah biasa yang terdiri atas pendahuluan, pembahasan, dan simpulan. Makalah dikumpulkan dan diklasifikasikan berdasarkan topik yang dibahas. Dari hasil kegiatan tersebut, dapat diketahui bahwa topik karya ilmiah bidang kewarganegaraan mecakup topik hukum, politik, Pancasila dan perundangundangan, keagamaan, dan kemasyarakatan.

\section{Deskripsi dan Analisis Data Pilihan Kata dalam Karya Ilmiah Mahasiswa Bidang Kewarganegaraan}

Aspek pilihan kata meliputi ketepatan pemilihan kata dan kesesuaian pemilihan kata. Agar dapat memilih kata dengan tepat, seorang penyusun makalah harus memiliki pengetahuan yang memadai tentang fungsi dan makna kata. Beberapa karya ilmiah telah menggunakan pilihan kata dengan tepat sesuai dengan referensinya, tepat dalam penggunaan istilah, dan tepat maknanya. Data berikut menunjukkan ketepatan pilihan kata.

(1) Ada lagi upaya yang dilakukan KPU dan Bawaslu agar pelaksanaan pemilihan umum dilakukan secara demokratis dan berjalan lancar. (DT 23) Pada beberapa karya ilmiah banyak pula penggunaan kata yang tidak tepat seperti dalam contoh berikut.

(2) Kebiasaan atau adat bersifat otonom dan spontan, sedangkan hukum merupakan suatu produk kekuasaan yang terorganisir. ((DT 4)

(3) Hukum perusahaan bertambah penting di mana perlu diusahakan adanya bentuk-bentuk perusahaan yang paling sederhana sampai kepada bentuk perusahaan yang menggunakan modal asing. (DT 5)

Kalimat (4) di atas menggunakan kata nonbaku, kata terorganisir seharusnya diganti dengan kata terorganisasi. Kata di mana dalam kalimat (5) tidak tepat. Kata tersebut merupakan kata terjemahan dari bahasa Inggris where. Kata tersebut seharusnya diganti dengan kata karena. 


\section{Deskripsi dan Analisis Data Struktur Kalimat dalam Karya Ilmiah Bidang Kewarganegaraan}

Keefektifan kalimat dapat dilihat dari segi strukturnya yang memenuhi syarat kesatuan, kesejajaran, kehematan, ketegasan/penekanan, dan keva riasian. Karya ilmiah bidang kewarganegaraan memiliki kekhasan dalam strukturnya, yaitu sebagian besar kalimat yang digunakan adalah kalimat majemuk, baik kalimat majemuk setara maupun kalimat majemuk bertingkat. Tentu saja penggunaan kalimat majemuk tidak menjadi persoalan bila mengikuti kaidah-kaidah keefektifan kalimat. Berikut ini data kalimat yang memenuhi keefektifan kalimat.

(4) Hukum publik mengatur hal-hal yang berkaitan dengan negara dan kepentingan umum (hukum tata negara), kegiatan pemerintahan (hukum administrasi atau tata usaha negara), kejahatan (hukum pidana), sedangkan hukum perdata mengatur hubungan antara penduduk atau warga negara seperti perkawinan, perceraian, kematian, pewarisan, harta benda, kegiatan usaha, dan tindakan yang bersifat perdata lainnya. (DT 10)

Kalimat di atas menggunakan kalimat yang majemuk bertingkat yang cukup panjang, tetapi ide atau gagasan kalimat dapat tersampaikan kepada pembacanya. Unsur-unsur subjek dan predikat jelas, hubungan antarunsur pun jelas.

\section{a. Kesatuan}

Kesatuan yang baik dalam kalimat akan terlihat dalam penggunaan unsurunsur fungsional dalam kalimat itu. Unsur subjek dan predikat sebagai unsur utama dalam kalimat digunakan secara eksplisit sehingga ide atau gagasan dapat dipahami pembaca. Berikut adalah data kalimat yang memperlihatkan kesatuan, sehingga kalimat menjadi efektif.

(5) Perubahan sosial adalah perubahan yang terjadi pada unsur-unsur sosial dalam kehidupan masyarakat, misalnya perubahan pada proses interaksi sosial, struktur sosial, lapisan sosial, nilai, norma atau kontrol sosial, dan lembaga-lembaga sosial.(DT 24)

Kesatuan kalimat menjadi rusak apabila dalam kalimat tidak ada salah satu unsur yang merupakan unsur utama dalam kalimat, sehingga gagasan yang ingin 
disampaikan tidak tersampaikan dengan baik. Dalam data berikut terdapat kalimat yang tidak memenuhi aspek kesatuan.

(6) Bahwa keamanan dan ketertiban itu adalah tanggung jawab bersama. (DT 13)

Kalimat (6) tidak memenuhi syarat kesatuan. Kalimat-kalimat tersebut tidak jelas subjeknya. Ketidakjelasan subjek pada kalimat (6) disebabkan oleh penggunaan kata depan pada awal kalimat. Agar kalimat di atas jelas subjeknya kata penghubung pada awal kalimat harus dihilangkan, perbaikannya adalah

(6a) Keamanan dan ketertiban masyarakat itu adalah tanggung jawab bersama.

\section{b. Kesejajaran (Paralelisme)}

Kesejajaran dalam kalimat meliputi Kesejajaran bentuk, kesejajaran makna, dan kesejajaran rincian pilihan. Pada dasarnya, dalam karya ilmiah bidang kewarganegaraan telah diterapkan kalimat yang memiliki ciri-ciri kesejajaran. Hal itu terdapat pada data berikut.

(7) Etika politik Pancasila mengamanatkan bahwa Pancasila sebagai nilai-nilai dasar kehidupan bermasyarakat, berbangsa, dan bernegara harus dijabarkan dalam bentuk perundang-undangan, peraturan, atau ketentuan yang dibuat oleh penguasa. (DT 19)

Akan tetapi, banyak pula kesalahan kesejajaran yang ditemukan dalam makalah yang ditulis mahasiswa. Sebagian besar kesalahan tersebut dikategorikan sebagai kesalahan bentuk kata dan kesalahan rincian pilihan, sedangkan kesalahan kesejajaran makna hanya sedikit. Di bawah ini penulis sajikan data kesalahan kesejajaran.

(8) Minat, rasa ingin tahu, kompetensi, serta mengaplikasikan mekanisme pengarahan diri dianggap sebagai kunci motivasi. (DT 22)

Kalimat (8) mengandung kesalahan kesejajaran bentuk kata dalam menyatakan gagasannya. Untuk memperbaikinya, kata-kata yang dicetak miring pada kalimat di atas harus diganti dengan bentuk kata yang sejajar dengan bentuk kata lainnya dalam kalimat-kalimat tersebut. Di bawah ini penulis sajikan perbaikannya.

(8a) Minat, rasa ingin tahu, kompetensi, serta pengaplikasian mekanisme pengarahan diri dianggap sebagai kunci motivasi. 


\section{c. Kehematan}

Aspek kehematan sangatlah penting untuk membentuk kalimat menjadi efektif. Agar kalimat memenuhi kehematan, banyak hal yang harus diperhatikan dalam menulis karya ilmiah, misalnya menghindari pengulangan subjek, menghindari pemakaian superordinat dalam hiponim kata, menghindari pemakaian kata yang tidak diperlukan, tidak menjamakkan kata yang berbentuk jamak, dan tidak menggunakan kata yang sinonim dalam satu kalimat.

Dalam tulisan yang ditelaah, aspek kehematan merupakan aspek yang belum diperhatikan oleh penulis makalah. Di bawah ini penulis sajikan data kalimat yang memenuhi syarat kehematan dan yang tidak memenuhi syarat kehematan.

(9) Keinginan untuk memiliki harta kekayaan dan barang-barang mewah dicapaiinya dengan jalan yang tidak wajar, yaitu melakukan tindak kriminal. (DT 21)

Kalimat (9) merupakan kalimat yang mengandung unsur kehematan. Walaupun kalimat tersebut cukup panjang, kata-kata yang digunakan tetap hemat.

(10) Jika kita harus menjaga agar supaya dalam Undang-Undang Dasar itu tetap sesuai dengan keadaan zaman. (DT 6)

Kalimat (10) tidak efektif karena menggunakan kata yang memiliki makna yang sama. Agar kalimat memiliki kehematan, harus dipilih salah satu di antara dua kata yang memiliki kesamaan makna tersebut. Perbaikan kalimat tersebut penulis sajikan di bawah ini.

(10a) Kita harus menjaga agar dalam Undang-Undang Dasar itu tetap sesuai dengan keadaan zaman.

(10b) Kita harus menjaga supaya dalam Undang-Undang Dasar itu tetap sesuai dengan keadaan zaman.

Kesalahan kehematan juga disebabkan oleh penjamakan kata yang sudah bermakna jamak. Data di bawah ini merupakan data kalimat yang tidak memenuhi aspek kehematan karena menjamakkan kata yang sudah bermakna jamak.

(11) Ada beberapa lembaga-lembaga negara di Indonesia sekarang ini salah satunya adalah Komisi Yudisial yang tercantum dalam pasal 24 B ayat 1,2,3, dan 4. (DT 26) 
Kalimat di atas akan menjadi efektif bila diubah seperti berikut.

(11a) Ada beberapa lembaga negara di Indonesia sekarang ini salah satunya adalah Komisi Yudisial yang tercantum dalam pasal 24 B ayat 1, 2, 3, dan 4.

(11b) Ada lembaga-lembaga negara di Indonesia sekarang ini salah satunya adalah Komisi Yudisial yang tercantum dalam pasal 24 B ayat 1, 2, 3, dan 4.

Penggunaan kata depan dari dan daripada yang tidak tepat akan menyebabkan kalimat tidak memiliki kehematan seperti dalam data berikut.

(12) Tujuan dari penyusunan dari makalah ini yaitu untuk mengetahui pentingnya demokrasi dalam kehidupan berbangsa dan bernegara. (DT 18)

Kalimat-kalimat di atas akan memiliki kehematan bila diubah menjadi kalimatkalimat berikut ini.

(12a) Tujuan penyusunan makalah ini untuk mengetahui pentingnya demokrasi dalam kehidupan berbangsa dan bernegara.

\section{d. Ketegasan/Penekanan}

Setiap kalimat memiliki ide pokok atau gagasan yang ingin dipentingkan. Bila kita ingin menonjolkan bagian kalimat yang dipentingkan dalam kalimat, ada berbagai cara, antara lain pemindahan letak frasa, penggunaan partikel penegas, pemindahan unsur kalimat, dan pengulangan kata yang diperlukan.

Dalam makalah bidang kewarganegaraan yang dianalisis, secara umum, penyusun telah menerapkan aspek penekanan pada kalimat-kalimatnya. Cara yang dilakukan penyusun makalah dalam memberikan penekanan dalam kalimat terdapat dalam data berikut ini.

(13) Di sinilah konsep-konsep hukum baru memegang peranan penting. (DT 5)

Pada data di atas terlihat bahwa aspek penekanan kalimat diterapkan dengan baik. Hal itu ditunjukkan oleh penggunaan partikel penegas -lah pada kalimat (20).

\section{e. Kevariasian}

Kevariasian dapat dilakukan misalnya menggunakan kalimat yang panjang dan kalimat yang pendek secara bergantian. Kalimat yang menggunakan pola yang sama atau menggunakan kalimat yang pendek terus-menerus akan menimbulkan 
kebosanan pada pembaca. Demikian pula penggunaan kalimat yang panjang terusmenerus akan membuat pembaca kehilangan pegangan tentang gagasan yang dikemukakan.

Ciri kevariasian akan diperoleh jika kalimat yang satu dibandingkan dengan kalimat yang lain. Dari data kalimat yang ditulis mahasiswa, kevariasian telah diterapkan pada sebagian makalah. Kevariasian itu dilakukan dengan melakukan variasi dalam pembukaan kalimat dengan frasa keterangan (waktu, tempat, cara) seperti terdapat pada data berikut.

(14) Di sinilah peran moral dan agama untuk menuntun manusia kepada jalan yang benar. (DT 20)

Kalimat di atas menggunakan variasi pada pembukaan kalimat dengan frasa keterangan tempat dan berpola K-S-P-O-K pada kalimat (14). Selain itu, digunakan pula partikel -lah sebagai penegas frasa keterangan tersebut sehingga variasi kalimat menjadi lengkap. Data lain menunjukkan penggunaan kalimat yang panjang tetapi dapat dipahami oleh pembacanya.

(15) Makin maraknya penyelundupan, pembunuhan, penganiayaan, pencurian, penggelapan, serta penyalahgunaan senjata api dan bahan peledak adalah indikasi belum tertanganinya secara serius masalah kriminalitas. (DT 13) Kalimat di atas cukup panjang, tetapi penggunaan kalimat yang bervariasi seperti itu membuat pembaca tidak bosan untuk membacanya.

Walaupun aspek kevariasian telah diterapkan dalam tulisan, ada pula tulisan yang masih menggunakan kalimat yang tidak bervariasi. Kalimat yang digunakan merupakan kalimat yang pendek-pendek dan berpola S-P-O. Berikut data kalimat yang tidak bervariasi.

(16) Motivasi penting untuk berprestasi dalam kehidupan manusia. Motivasi berkorelasi positif dengan prestasi di berbagai tingkat pendidikan. Prestasi tinggi suatu bidang diasosiasikan dengan motivasi tinggi. Kurang motivasi dihubungkan dengan prestasi yang rendah. (DT 22)

Dalam data di atas terlihat bahwa kalimat yang digunakan adalah kalimat yang pendek-pendek dan pola yang digunakan adalah pola umum yaitu subjek berada di depan predikat. 


\section{f. Kelogisan Kalimat}

Kalimat yang wujudnya lengkap mengandung subjek, predikat, objek, dan keterangan, sedangkan kalimat yang wujudnya tidak lengkap unsur-unsurnya pun tidak lengkap seperti pada kalimat seru, kalimat jawab, atau kalimat perintah. Bila kalimat yang dituliskan kacau susunannya, itu bukti bahwa pikiran penulisnya pun kacau. Logika tidak berjalan dengan baik atau penalaran tidak sempurna.

Logika atau penalaran yang benar akan melahirkan kalimat yang bernalar. Pada umumnya makalah yang dianalisis telah menerapkan kalimat yang sesuai dengan logika, tetapi banyak pula kesalahan logika yang ditulis dalam makalah tersebut. Data kalimat yang menggunakan kalimat yang bernalar atau sesuai dengan logika terdapat di bawah ini.

(17) Hukum adalah peraturan yang bersifat memaksa yang menentukan tingkah laku manusia dalam lingkungan masyarakat yang dibuat oleh badan-badan resmi yang berwajib. (DT 5)

Di bawah ini penulis sajikan pula data kalimat yang menunjukkan kesalahan logika.

(18) Setiap pelanggaran-pelanggaran yang dilakukan akan ditindak tegas sesuai dengan peraturan dan perundang-undangan yang berlaku di setiap negara. (DT 26)

Kalimat di atas mengandung kesalahan logika. Hal itu ditunjukkkan oleh frasa setiap pelanggaran-pelanggaran. Kata setiap bermakna satu, tetapi pada kalimat itu dirangkaikan dengan kata pelanggaran-pelanggaran yang bermakna jamak. Oleh karena itu, kalimat akan bernalar bila frasa itu bermakna satu, yaitu setiap pelanggaran. Jadi, perbaikannya adalah

(18a) Setiap pelanggaran yang dilakukan akan ditindak tegas sesuai dengan peraturan dan perundang-undangan yang berlaku di setiap negara.

\section{Deskripsi dan Analisis data Penerapan Kaidah Ejaan dalam Karya Ilmiah Bidang Kewarganegaraan.}

Banyak penulis makalah yang tidak memperhatikan kaidah ejaan dalam tulisannya, padahal ejaan merupakan hal yang sangat penting dalam sebuah tulisan 
sebab penulis dan pembaca tidak bertatap muka. Agar sebuah kalimat memenuhi keefektifan, penerapan kaidah ejaan harus diperhatikan sehingga kalimat dapat dipahami dengan baik oleh pembacanya.

Pada makalah yang ditulis oleh mahasiswa, sebagian kalimatnya sudah menerapkan kaidah ejaan dengan benar, tetapi banyak pula yang masih salah menerapkan kaidah ejaan. Kesalahan ejaan yang ditemukan meliputi kesalahan penulisan huruf, kesalahan penulisan kata, dan kesalahan pemakaian tanda baca.

\section{a. Penulisan Huruf}

Sebagian besar kesalahan penulisan huruf dalam makalah mencakup kesalahan penulisan huruf kapital. Masih terdapat kekeliruan kata yang harus menggunakan huruf kapital dan kata yang harus menggunakan huruf kecil. Selain itu, terdapat kesalahan penggunaan huruf miring. Data kesalahan penulisan huruf kapital disajikan sebagian karena kesalahannya menunjukkan kesamaan.

(19) Di Negara yang sudah maju pelaksanaan hukum .... (DT 4)

(20) Negara indonesia adalah negara hukum. (DT 10)

Kata negara pada kalimat (19) tidak perlu menggunakan huruf kapital karena tidak maengacu pada nama. Sebaliknya, kata indonesia harus menggunakan huruf kapital. Kata Indonesia mengacu pada nama negara.

(19a) Di negara yang sudah maju pelaksanaan hukum ....

(20a) Negara Indonesia adalah negara hukum.

\section{b. Penulisan Kata}

Kesalahan penulisan kata yang pertama dalam makalah yang ditulis mahasiswa adalah kesalahan dalam membedakan penulisan kata depan di- dan kesebagai awalan dengan penulisan di dan ke sebagai kata depan, seperti kata dibuat ditulis di buat dan kata di samping ditulis disamping. Seharusnya penulisan kata depan di dipisahkan dari kata yang mengikutinya. Data kesalahan tersebut terdapat di bawah ini.

(21) Berdasarkan hal tersebut diatas .... (DT 15)

(22) Untuk menyelamatkan perekonomian sampai kepelosok desa .... (DT 9)

Perbaikan kalimat-kalimat di atas adalah sebagai berikut.

(21a) Berdasarkan hal tersebut di atas .... 
(22a) Untuk menyelamatkan perekonomian sampai ke pelosok desa ....

Penulisan di- sebagai awalan harus dirangkaikan dengan kata yang mengikutinya. Pada makalah juga masih banyak kesalahan penulisan awalan di-. Data berikut menunjukkan kesalahan penulisan awalan $d i$ - beserta perbaikannya.

(23) Atas dasar pemikiran itulah perlu di lakukan upaya pencegahan ....(DT 11) Perbaikannya adalah

(23a) Atas dasar pemikiran itulah perlu dilakukan upaya pencegahan ....

Kesalahan penulisan kata yang kedua adalah kesalahan penulisan -pun sebagai partikel dan pun sebagai kata yang artinya juga. Partikel -pun seharusnya ditulis serangkai dengan kata dasarnya, sedangkan kata pun seharusnya ditulis terpisah dari kata dasarnya. Data kesalahannya terdapat di bawah ini.

(24) Walau pun cita-cita bangsa Indonesia belum .... ( DT 19)

(25) ... kemerdekaan warga negarapun .... (DT 28)

Perbaikan kalimat-kalimat di atas adalah berikut ini.

(24a) Walaupun cita-cita bangsa Indonesia belum ....

(25a) ... kemerdekaan warga negara pun ....

Kesalahan penulisan kata yang ketiga adalah kesalahan penulisan kata gabung. Penulisan kata gabung yang tidak mendapat imbuhan seharusnya dipisahkan, penulisan kata gabung yang hanya mendapat awalan atau hanya mendapat akhiran seharusnya yang disatukan dengan kata yang mendapat awalan atau akhiran tersebut saja, dan penulisan kata gabung yang mendapat awalan dan akhiran sekaligus disatukan. Data kesalahan penulisan kata gabung tersebut adalah sebagai berikut.

(26) Partisipasi warganegara dalam pembangunan .... (DT 6)

(27) ... munculnya semangat kedaerahan, ketidak pedulian .... (DT 6)

Kalimat-kalimat di atas lebih efektif bila diubah seperti berikut.

(26a) Partisipasi warga negara dalam pembangunan ....

(27a) ... munculnya semangat kedaerahan, ketidakpedulian ....

\section{c. Pemakaian Tanda Baca}

Tanda baca dalam tulisan merupakan hal yang sangat penting agar pembaca mengetahui maksud penulis dengan jelas. Sebagian makalah yang ditulis 
mahasiswa telah menerapkan pemakaian tanda baca dengan benar, tetapi sebagian lagi masih banyak kesalahan menerapakan tanda baca dalam kalimat. Kesalahan tersebut terdapat pada data berikut.

(28) Akan tetapi terdapat perkembangan yang .... (DT 4)

(29) Bangkitnya nasionalisme dipengaruhi oleh tiga faktor, yaitu kemajuan pendidikan, diskriminasi dan pengaruh paham baru. (DT 8)

Kalimat (28) tidak menggunakan tanda koma setelah kata penghubung awal kalimat. Kalimat-kalimat itu akan jelas bila dibubuhi tanda koma. Kalimat (29) tidak menggunakan tanda koma pada pemerian. Perbaikan kedua kalimat tersebut adalah

(28a) Akan tetapi, terdapat perkembangan yang ....

(29a) Bangkitnya nasionalisme dipengaruhi oleh tiga faktor, yaitu kemajuan pendidikan, diskriminasi, dan pengaruh paham baru.

\section{SIMPULAN}

Berdasarkan analisis hasil pembahasan dapat disimpulkan hal-hal berikut.

1. Struktur kalimat karya ilmiah bidang kewarganegaraan berbentuk kalimat tunggal dan kalimat majemuk. Penggunaan kalimat majemuk dimaksudkan untuk menjelaskan ide atau gagasan utama dalam kalimat.

2. Penerapan kaidah kalimat efektif dalam karya ilmiah mahasiswa Jurusan PIPS Prodi PPKn dari segi diksi, struktur, dan logika masih memiliki banyak kesalahan sebelum bahan ajar kalimat efektif digunakan dalam perkuliahan.

3. Kualitas karya ilmiah setelah bahan ajar kalimat efektif diujicobakan adalah berikut ini.

a. Penerapan aspek pilihan kata dan istilah dalam karya ilmiah baik. Hal ini ditandai dengan penggunaan kata yang tepat, lazim, dan benar dalam kalimat. Istilah-istilah digunakan dengan tepat pula.

b. Penerapan aspek kesatuan dalam karya ilmiah baik. Hal ini terlihat dalam penggunaan unsur-unsur kalimat secara eksplisit seperti subjek dan predikat. 
c. Penerapan aspek kesejajaran dalam karya ilmiah baik. Hal ini ditandai dengan penggunaan bentuk kata dan frasa yang sejajar, penggunaan jenis kata yang sama, dan penggunaan rincian pilihan yang sejajar pula.

d. Penerapan aspek kehematan dalam karya ilmiah setelah bahan ajar digunakan baik. Ini terlihat pada kalimat-kalimat yang tidak menggunakan kata-kata mubazir.

e. Penerapan aspek ketegasan/penekanan dalam karya ilmiah setelah bahan ajar digunakan sudah baik. Kalimat-kalimat sudah menggunakan kata dan partikel penegas, menggunakan frasa yang dipentingkan dalam kalimat, dan menggunakan kata penghubung intrakalimat yang berfungsi sebagai penegas.

f. Penerapan aspek kevariasian dalam karya imiah setelah bahan ajar digunakan baik. Kalimat-kalimat sudah memiliki variasi pembukaan kalimat, variasi jenis kalimat, dan variasi pola kalimat.

g. Penerapan aspek kelogisan dalam karya ilmiah setelah bahan ajar digunakan baik. Kalimat-kalimat sudah sesuai dengan logika berpikir dan tidak menimbulkan tafsiran yang berbeda.

h. Penerapan kaidah ejaan dalam karya ilmiah bidang kewarganegaraan setelah bahan ajar digunakan cukup baik. Hal ini ditandai dengan berkurangnya kesalahan penulisan huruf besar dan huruf kecil, kesalahan penulisan kata, dan kesalahan pemakaian tanda baca.

Dari hasil temuan dan kesimpulan penelitian ini direkomendasikan beberapa hal. Pertama, kemampuan menggunakan kalimat efektif dalam menulis karya ilmiah merupakan salah satu komponen yang harus dimiliki oleh mahasiswa Jurusan PIPS Prodi PPKn. Kedua, bahan ajar kalimat efektif yang digunakan harus relevan dan aktual. Ketiga, bahan ajar kalimat efektif yang dilengkapi dengan contoh kalimat dalam wacana bidang kewarganegaraan perlu digunakan dalam perkuliahan di Jurusan PIPS Prodi PPKn untuk meningkatkan penggunaan kalimat efektif dalam karya ilmiah. 


\section{DAFTAR PUSTAKA}

Arifin, E. Z. (2006). Dasar-dasar Penulisan Karangan Ilmiah. Jakarta : Gramedia.

Arifin, E. Z., \& Tasai, S. A. (2006). Cermat Berbahasa Indonesia. Jakarta: Akademika Pressindo.

Arikunto, S. (2002). Prosedur Penelitian: Suatu Pendekatan Praktek. Jakarta : Rineka Cipta.

Badudu, J.S. (1993). Inilah Bahasa Indonesia yang Benar IV. Jakarta : PT Gramedia.

Djamarah, S, B., \& Zain, A. (2006). Strategi Belajar Mengajar. Jakarta: Rineka Cipta.

Panitia Pengembang Pedoman Bahasa Indonesia. (2016). Pedoman Umum Ejaan Bahasa Indonesia. Jakarta: Badan Pengembangan dan Pembinaan Bahasa Kementrian Pendidikan dan Kebudayaan.

Prasetyo, E. (2013).Penggunaan Kalimat Efektif dalam Naskah Dinas di Kantor Desa Temuku, Kecamatan Mejobo, Kabupaten Kudus. dalam eprints.ums.ac.id/26654/24/Naskah-Publikasi.pdf. Diakses tanggal 15 Maret 2019.

Putrayasa, I.B. (2007). Kalimat Efektif :Diksi, Struktur, dan Logika. Bandung : Refika Aditama.

Nurhayatin, T, dkk. (2018). Analisis Keefektifan Penggunaan Kalimat dalam Karya Tulis Ilmiah Mahasiswa Pendidikan Guru Sekolah Dasar. JPSD Vol.4 No. 1. Maret 2018 dalam Jurnal.untirta.ac.id/index.php/jpsd/article/download/2911/2371 . Diakses tanggal 15 Maret 2019. 